\title{
DEVELOPING ISLAMIC WAQF BANK AS A MECHANISM FOR FINANCIAL SYSTEM STABILITY
}

\author{
Muhammad Ridhwan Ab. Aziz ${ }^{1}$
}

\begin{abstract}
The establishment of Islamic banking institution all over the world is often related to the proclivity of muslims to live all aspects of their lives in accordance with the teachings of Islam. Islamic bank is one of the components in Islamic financial sector that plays very vital role to generate the growth of economics among muslim society. Indeed, Islamic bank was more robust to the financial crisis compared to the conventional banking institution. Cash waqf is a trust fund established with money to provide services to mankind in the name of Allah. The gifted capital then will be spent for all sorts of pious and social purposes inclusive for the financing and investment objectives. It is recognized that there is limited study in the area of cash waqf especially in the development of Islamic waqf bank (IWB). The main objective of this article is to analyze the possibility and obstacles in developing IWB in the mainstream Islamic financial institutions. The methodology of research in this article is through a qualitative research based on interview with relevant officers in the Islamic banking, waqf, and academic sectors. The general finding in this article shows that IWB can apply cash waqf structure, whereby the cash waqf fund must be converted into fixed assets such as land and buildings. The rental income from the fixed assets and investments then can be channelled to waqf beneficiaries such as funding students' education, health assistance, giving financing to the entrepreneur, and enhancing muslim economy in various fields. Nevertheless, a proper mechanism of IWB must be developed in order to avoid any obstacles in terms of capital requirement, risky investment, limited number of experts in the field of Islamic bank and waqf as well as legal and regulation requirement.
\end{abstract}

Keywords: Islamic Waqf Bank, Cash waqf, Islamic finance, Financial system stability

JEL Classification: G21, I31, L31

Received: July 14, 2016; Revised: July 12, 2017; Accepted: August 21, 2017

1 Associate Professor at Faculty of Economics and Muamalat, Universiti Sains Islam Malaysia, Bandar Baru Nilai, 71800, Negeri Sembilan, Malaysia. Tel: +606-7986410.

E-mail: ridhwan.aziz@usim.edu.my 


\section{INTRODUCTION}

\subsection{Background}

The global Islamic finance industry has expanded rapidly in the past few years, with assets growing at a double-digit compound annual growth rate (CAGR) of $17 \%$ between 2009 and 2013. The rising appeal of shariah compliant finance was supported partly by religious and ethical preferences by both muslim and non-muslim communities in selected countries. In line with the primary goals of Islam, the eradication of poverty, socio-economic justice, and equitable distribution of income are features of a shariah-compliant financial system. There are various social institutions and structures in Islam that reflects both income and wealth redistribution for the fulfilment of the basic needs for all in the society and the institutions include, among others waqf, which is more commonly known as Islamic endowment. Through waqf, the gap present between contemporary Islamic finance and its socio-economic aspects can therefore be addressed (Islamic Financial Services Industry Financial Stability Report, 2015).

Waqf refers to a religious endowment i.e. a voluntary and irrevocable dedication of one's wealth or a portion of it - in cash or kind, and its disbursement for shariah-compliant projects. With proper structuring and administration, it can provide perpetual benefit to the society. Waqf is considered as a virtuous act, and was seen as the pillar of the religious, social, cultural, scientific, economic, and political life of the Islamic society. The economic success of waqf was manifested during the reign of the Ottoman Empire, where waqf were highly developed and played a crucial role in the social and economic order of the Empire. Through waqf, the Empire managed to accumulate large revenue and savings and achieved budget surpluses (The Star Online, April 15, 2014).

In Malaysia, the developments of waqf activities and institutions have expanded in terms of financial value and innovation in the recent years. From an economic perspective, waqf can be regarded as a type of savings-investment mechanism where funds are diverted from consumption and invested in productive assets that provide revenue. The proceeds can be used to achieve social objectives such as building hospitals, orphanages, universities, etc., 
thus unlocking both its economic potential and philanthropic objectives. In this regard, the development of IWB may benefit many people especially among student, entrepreneur, and also the donor whereby they able to obtain financing and other financial facilities through this bank and at the same time, the donor who wish to donate their money able to do so by contributing to the IWB that will be managed profesionally. Here, both individuals, deficit and surplus unit may grab huge opportunity for a specific goals, with shariah approved financial transaction.

\section{CONCEPT OF WAQF AND CASH WAQF}

The word waqf is derived from the Arabic root verb "waqafa" means 'causing a thing to stop and standstill'. It also takes the meanings of 'detention', 'holding' or 'keeping'. Waqf which (pl. awqaf) is called Boniyad in Iran and Habs (pl. ahbas) in North and West Africa. However, by taking its different meanings into consideration waqf can be applied to non-perishable property whose benefit is extracted without consuming the property itself. Although, waqf is not specifically mentioned in the Holy Quran, the concept of wealth distribution is strongly emphasized therein (Chowdhury, Ghazali, \& Ibrahim, 2011; Aziz, 2012). Distribution of wealth is a key issue in the modern economy to make it more dynamic, prejudice free, and entrepreneurial. However, a hadith narrated by Abu Hurairah [May Allah be pleased with him (RA)] is considered as the origin of this institution in the world of Islam. "Abu Hurairah (RA) reported Prophet Muhammad [SAW] as saying: when a man dies, all his acts come to an end, but three; recurring charity (sadaqah jariyah) or knowledge (by which people are benefited), or a pious offspring, who prays for him" (Reported by Muslim, No. 4223).

From shariah point of view, waqf may be defined as holding a mal (an asset) and preventing its consumption for the purpose of repeatedly extracting its usufruct for the benefit of an objective representing righteousness or philanthropy. This definition also covers several new forms of waqf that were not discussed in the classical literature, such as the waqf of financial rights and waqf of usufruct, are covered by the definition of the word mal (asset) according to the majority of fuqaha and as expressly mentioned in the collective fatawa, especially the OIC Figh Academy (Kahf, 1998). 
The contemporary jurists also justify the validity of the cash waqf, because it is in the interest of the waqf, its beneficiaries and the society (Mohammad, 2011; Aziz et al., 2014).

In addition, waqf assets can also be immoveable or moveable (e.g. cash waqf). In cash waqf, al-waqif (donor) endowed cash instead of real estate. Cash waqf begin in primeval Mesopotamia, Greece, and the Roman Empire. In fact, in the eighth century, Imam Zufar had approved cash waqf in the Islamic World for the first time. According to him, cash waqf would be invested through mudarabah and profits would be spent for charity. Nevertheless, cash waqf did not expand and mature until the $16^{\text {th }}$ century and after that century it became popular, especially among the Ottomans. Although there was controversy on the legality of cash waqf among the shariah scholars but thousands of cash waqf continued to be endowed. In particular, cash waqf was supported by the Ottoman Sultans, because funds were financed in the expansion of Islam in Europe (Çizakça, 2004, 2010).

Many muslim did not get chance to participate in waqf endowment because there is a wrong perception among muslims that there may be waqf endowment through only land not in cash. They believe land can fulfill the three conditions of waqf such as perpetuity, irrevocability, and inalienability. However, land may be subject to demolition, destruction due to the natural calamity, and waqf will only last till its value exist (Mohammad, 2008). Through proper cash waqf management, it is easily possible to hold waqf value as well as value enhancement. As a result, those who do not have land can participate in endowment through cash waqf. In addition, nowadays people have more choices for waqf by including cash into waqf.

Meanwhile, cash waqf is charitable endowments established with cash capital. What distinguishes these from the standard real estate endowments is the nature of their capital, corpus, which is in the form of cash. The corpus of the real estate waqf, by contrast, is in the form of real estate. Furthermore, cash waqf is far more important since it is more productive compared to land, buildings, books, cattles, and so on, as it is testified by the existing research studies and have been found profitable in the practices of modern Islamic financial system. 
In fact, in cash waqf the amount or value of the waqf is not an important issue, rather it is worthy to involve whole ummah in the process of waqf, so that everyone irrespective of financial condition could be involved by contributing as little as a cent within the prescribed systems of institutionalizing the concepts under government or private initiatives and guidelines provided by Islamic doctrines (Chowdhury et al., 2011). That is anyone, subject to certain shariah conditions, can be al-waqif (donor) through cash waqf.

Cash waqf can only be distributed and allocated for anything not against the shariah Law. This form of waqf provides opportunities for facilitating its participation in social development (Laila, n.d.):

a. Mass Participation: It provides an opportunity for participation of all segments of the muslim society and not just the wealthy muslims, like in the case of real property waqf. This gives every interested muslim a chance to participate, contribute with whatever means he has to offer, even with the simplest amount.

b. Rightful Utilization: Cash waqf scheme can gather the scattered endowments to create a common fund to maximize its utilization rather than the endowment being spent in mere consumer consumption. This lends itself to employ an efficient management scheme of modern financial system and thereby protect waqf being destroyed by incompetent mutawallis.

c. Social and Economic Development: Such a scheme can enhance the government's national development plan for poverty eradication and social services through co-ordination. In fact, the fund raised by cash waqf scheme can be used to fund microfinance projects which are currently funded by high interest rate and charges.

The study of cash waqf was done by several researchers in recently time. Çizakça (1998) explains that historical evidence indicates that the real exiting potential lies in the cash awqaf. The awqaf system has provided throughout Islamic history all the essential services at no cost to the state and a successful modernization of the system implies a significant cut in government expenditure and all the associated benefits including downsizing the state sector and a reduction or elimination of riba. Toraman, Tuncsiper, and Yilmaz (n.d.), conclude that in a society where health, education, and 
welfare were entirely financed by gifts and endowments, the cash awqaf carried serious implications for the very survival of the Ottoman social fabric.

Islahi (1992), stated that the internationalize the voluntary institution of awqaf is needed nowadays, by setting up a nongovernment world muslim foundation which should provide public goods on large scale and in much more significant fashion than has been the case up till now, to combat illiteracy, sickness, and lack of technical know-how. Kahf (1998), explains the importance of waqf for socio-economic development, which is consists of creating and developing a third sector distinct from the profit-motivated private sector and the authority-based public sector, and changing this third sector with the responsibility of performing a group of tasks whose nature make them better achieved. This third sector assigned in education, health, social, and environmental welfare. Furthermore, it can provide defense services and public utilities in many instances.

Chowdhury et al. (2011) explain that cash waqf would also help to reform the present institutional setup and their networking relationship throughout the country with a view to increasing their performance in the direction of the efficient and need based dynamic management of the waqf affairs and systems which total policy dimensions at micro and macro mixed with the diversified objectives of innovations and development in the waqf management systems complying with the shariah guidelines. Mohammad and Iman (2006) explain that the new formulation of waqf may be realized by making a distinction between the perpetuity of the physical being of the object and it is not 'dedication' of benefits. New form of waqf can be declared in the non-traditional way. Old waqf, however, may still remain subject to the old conditions as long the greater interests of the waqf are not threatened by these conditions.

Wafa (2010) explains that the impact of Developing Waqf for Education in Malaysia not only promoting the significant rule of waqf towards the country, but also will be impact to: (a) promoting the third sector of Islamic economic; (b) establishing economic activities through several projects and business; (c) complementing the royal aid development, benevolent, and educational programs; and (d) promoting the oneness of society. Mohammad (2011 explains 
that the waqf bank can be applied as the bank of the poor. It can be permissible in Islam based on validity of cash waqf and the need of waqf, its beneficiaries as well as the society. But, if there is a favourable political will, the institution of waqf through waqf bank may contribute to society greatly. The institutions of waqf have the unrealized potential to establish a waqf bank.

In Islam, education is considered as one of very important tools for the development of ummah materially and spiritually. Nevertheless, the limited number of financing mechanism for funding in free education makes some of the muslim community are unable to further their studies. Thus, by realizing the establishment of Islamic waqf bank, it may help to promote free education among muslim and finally able to enrich the development of muslim ummah through proper and systematic way of funding in education. This may increase the total number of muslim scholars in various fields in the future (Aziz et al., 2014).

\section{METHODOLOGY OF RESEARCH}

This research is a qualitative research based on interview with relevant officers. Interviews form a significant part of the empirical data. Interviews play a crucial role for the robustness of this study. Thus, the purpose of interview is to get other people's perspectives and how they render meanings on events of interest or the process of getting information out of their thinking (Marginson, 2004). The process of getting inside interviewees thought has the potential to offer a greater understanding of how waqf works in their organization and how this research can develop the structure of IWB. Therefore, interview is considered as a conversation with purpose of acquiring knowledge from interviewees. In this research, a semistructured interview is employed to flesh out the theory underpinning the holistic waqf structure (O'Dwyer, 2004).

The semi-structured interview is used since it offers greater opportunities to tap into realities beyond the interviews' contexts as compared to a structured interview. The semi-structured interviews were carried out based on an interview guide. A semi-structured interview informed by prior understanding can guide the process but not to the point of structuring the queries (Irvine \& Gaffikin, 2006). 
These are the two tasks that the interviewer or researcher must always bear in mind:

a. To follow researcher own line of inquiry, as reflected by interview protocol.

b. To ask actual (conversational) questions in an unbiased manner. If an interviewer only assumes the task (a) of following his/her own line of inquiry, it might be possible that this research be inclined towards a structured interview, which could also be found in a positivist approach because the interview might serve as a diagnostic effort. On the other hand, if only task (b) is emphasized, it would bear similarity to an unstructured interview, which might be found more often in an interpretive approach (Ahrens \& Chapman, 2006).

A total of 13 respondents were interviewed in a semi structured interview for the same set of questions. The interview was utilized to understand the issue regarding IWB from respondents who have in-depth knowledge regarding waqf and Islamic banking. Due to the complexity of the subject matter, not all officers in the organization were interviewed. Only those who are expert in the field of waqf and Islamic banking were interviewed. Those who were not interviewed were officers who were not involved in day-to-day operation of waqf (State Islamic Religious Council) and Islamic banking (Islamic banking sector). The lists of respondents profile from each category of respondents are listed in Table 1.

Table 1.

Respondent Detail

\begin{tabular}{lllll}
\hline No & Respondents Code & & Particular & \\
\hline $\mathbf{1}$ & AA0001 & Muslim scholar & PhD holder & Respondent no1 \\
$\mathbf{2}$ & AA0002 & Muslim scholar & PhD holder & Respondent no2 \\
$\mathbf{3}$ & AB0003 & Muslim scholar & Master holder & Respondent no3 \\
$\mathbf{4}$ & AA0004 & Muslim scholar & PhD holder & Respondent no4 \\
$\mathbf{5}$ & AA0005 & Muslim scholar & PhD holder & Respondent no5 \\
$\mathbf{6}$ & BB0001 & Waqf Institution & Executive & Respondent no1 \\
$\mathbf{7}$ & BA0002 & Waqf Institution & Manager & Respondent no2 \\
$\mathbf{8}$ & BB0003 & Waqf Institution & Executive & Respondent no3 \\
$\mathbf{9}$ & BB0004 & Waqf Institution & Executive & Respondent no4 \\
10 & CA0001 & Banking Institution & Manager & Respondent no1 \\
11 & CA0002 & Banking Institution & Manager & Respondent no2 \\
12 & CA0003 & Banking Institution & Manager & Respondent no3 \\
13 & CB0003 & Banking Institution & Executive & Respondent no4 \\
\hline
\end{tabular}

Source: Developed for Current Study 


\section{THE POSSIBILITY OF DEVELOPING ISLAMIC WAQF BANK (IWB)}

There is potential for developing IWB in Malaysia since a waqf organizations and Islamic banking organizations are already existed in Malaysia. IWB needs an expert in waqf and Islamic banking field. Therefore, State Islamic Religious Centre (SIRC) and Islamic bank should cooperate to establish IWB as this cooperation is essential in view of the fact that both organizations could monitor any waqf related activities at each state regularly.

The concept of Islamic banking business is the bank would purchase a non-movable asset like a premise which can later be sold and buyer pays by installment. From the perspective of Islamic banking system, if the system can be transformed into waqf banking system that buys and later rent out so that the revenues can be channelled to the tawzi' fund (distribution fund), then this bank could be developed. IWB can fully operate as other Islamic banks. In terms of marketing, when the bank offers products like waqf, it does not need to market the product. This is because the public will know if they want to contribute to waqf, they can directly deal with the bank (Respondent BB0003).

Based on Malaysia legal aspect, the mu'amalah law has been applied by the federal government by creating Islamic banking act. Meanwhile, from the Islamic legislative aspect, it is subject under the jurisdiction of the state government, not the federal government. Therefore, the Islamic banking system is under the Islamic legal system and should be under the jurisdiction of the state government. Since the Islamic banking system is considered a financial matter, it is therefore under the jurisdiction of the federal government. If the cash waqf can be considered as a financial matter, the federal government can also create a waqf banking system. Another way to solve this problem is to create waqf banking act. This provides a better and effective way as there is no such barrier after waqf bank's act is accomplished. From the shariah point of view, there is no offense to collect or raise cash for the purpose of developing IWB (Respondent AA0005).

The easiest way to establish IWB is by using the same procedures like other corporate banks. IWB can adapt the same Islamic banking activities same as other Islamic banks. To carry out 
waqf activities, IWB can adapt the way conventional banks practice Islamic window. IWB can use this example to be applied into their operation which is an Islamic banking system that has waqf window (Respondent AA0005).

In terms of capital requirements, the possible minimum capital basis is RM300 million. There are also requirements in terms of how the capital should be calculated based on asset risk, business risk, and so many acts that IWB needs to arbitrate. As for SIRC, their contributions come from waqf funds they receive from the public. So, SIRC is the representative or trustee. IWB can engage the SIRC of each state to contribute to the development of the waqf bank. The one who contributed or acquired more shares may be appointed as the Board of Directors (Respondent CA0002).

If the IWB can be developed with the cooperation of the SIRC as the representative of the trustee for the funds donated by the banking institutions based on shariah, and it is a practical suggestion. This is because the SIRC has no expertise to set up a banking institution. So, the fastest way is for the SIRC collaborates with Islamic banking institutions to support the development of this IWB. In this way, experts in banking and management of waqf funds can be put together under one roof. Meanwhile, the bank's direction must coincide with the original purpose of the development of the bank as well as waqf funds in order to expand the growth of the fund (Respondent CA0002).

To develop or establish IWB, shareholders are needed to buy the issued share. IWB shareholders can come from SIRC's of each state in Malaysia. In order to obtain expertise in the waqf and banking area, SIRC has to cooperate with the banking sector to form IWB. This is why SIRC and GLC companies especially the banking sector has to cooperate to make IWB a reality. Other than SIRC and GLC companies, cash waqf also has the potential to be IWB capital. If the waqif can understand the purpose of the establishment of IWB and willing to give his or her cash as waqf for the purpose of setting up the bank, cash waqf can be used as IWB capital. Furthermore, a mosque is also a potential entity to be IWB shareholder. This is because the mosques have a very large amount of savings up to RM500 thousand to RM1 million in selected places (Respondent CA0002). 


\section{Cash Waqf Structure for IWB}

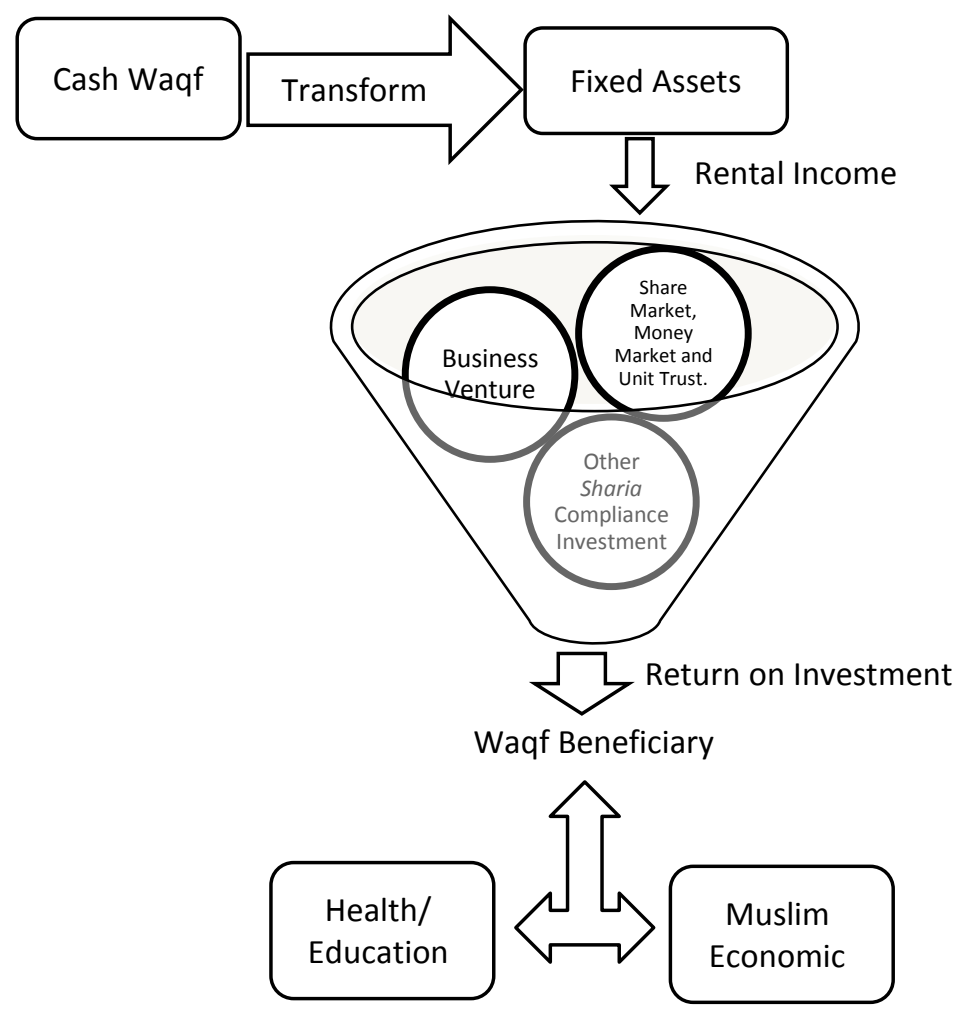

Figure 1.

Cash Waqf Structure for IWB

Practically, IWB can apply cash waqf structure as shown in Figure 1 above. The cash waqf fund must be converted into fixed assets such as land and buildings. The rental income from the fixed assets can be invested in share markets, money market, unit trust, business venture, and other shariah compliance investment to maximize the profit from waqf assets. The return from investments then can be channelled to waqf beneficiaries such as funding students' education and developing the muslim economy (Respondent AA0005, BB0001, BB0003, BB0004, CB0003). 


\section{The Governance Structure of IWB}

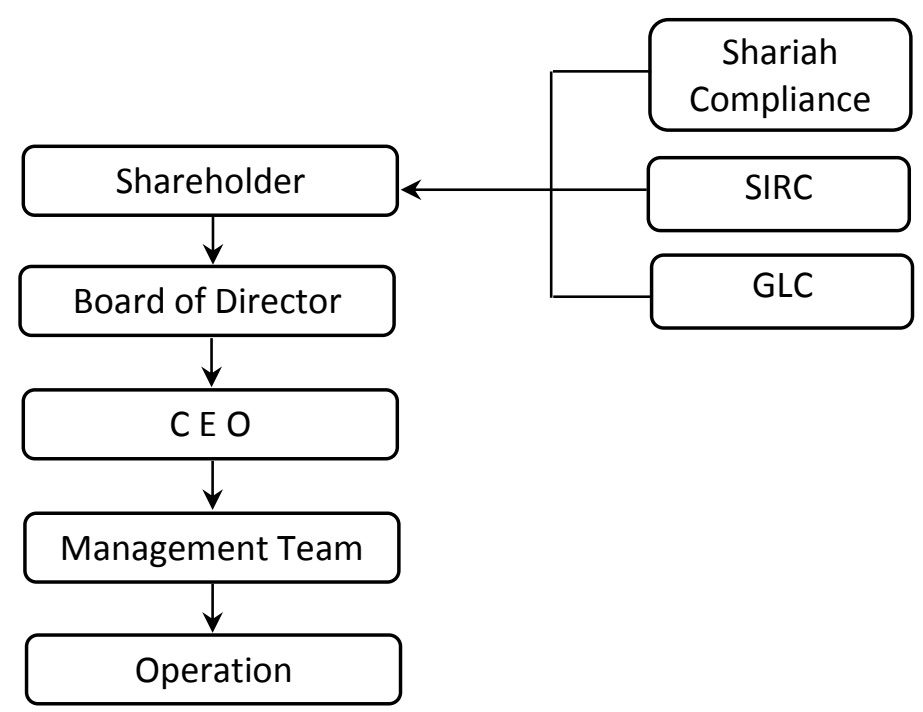

Figure 2.

The Governance Structure of IWB

Figure 2 shows the governance structure of IWB. The shareholder of IWB comes from a shariah compliant company, SIRC, and GLCs'. Since the three investors or the shareholders encompass expertise in banking and waqf, this allows them to assign and form their selected BOD while the CEO is appointed by the BOD. The CEO will then employ and constitute a management team for the company and the management team will hire the operation team who will run the operation of IWB (Respondent CA0002). 
The Structure of IWB

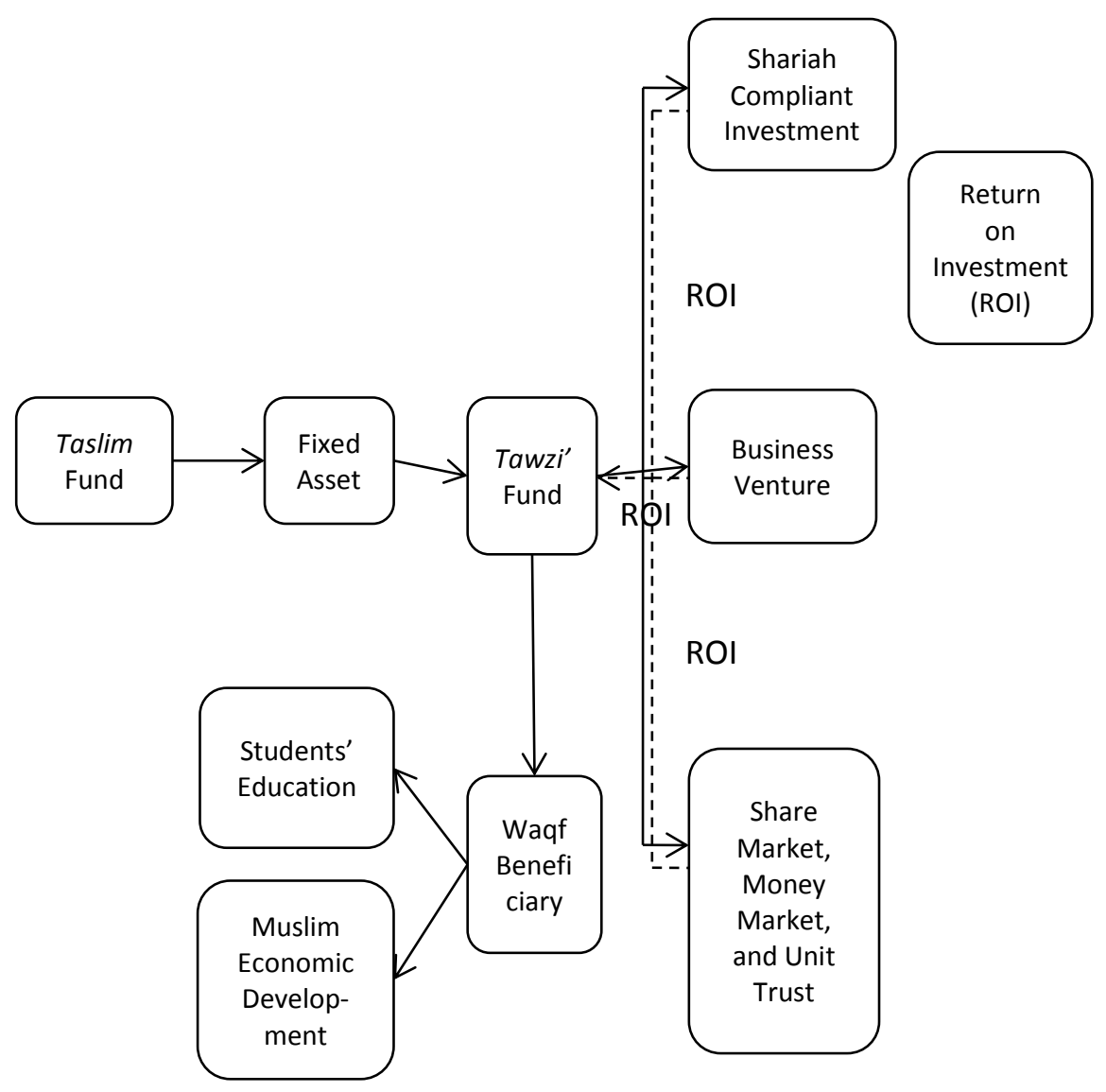

Figure 3.

The Structure of IWB

Figure 3 shows the depiction of the structure of IWB. The cash waqf structure has two main fund namely taslim and tawzi' fund. $\mathrm{ROI}$ is returned to tawzi' fund before it can be distributed to a waqf beneficiaries. In the case of IWB, a waqf beneficiaries might be the student, entrepreneur and muslim community. Tawzi' funds will be used to finance students' education and develop the muslim economy (Respondent AA0001, AA0002, AA0004, BB0003, BB0004, CA0001). 


\section{OBSTACLES IN DEVELOPING ISLAMIC WAQF BANK}

Although there is a constructive way to realize the development of IWB, but this idea needs to consider the various issues and obstacles as follows:

\subsection{Capital Requirement}

If waqif understands the purpose of the development or establishment of the IVB and prepares to donate his property for the purpose of setting up the bank, the cash waqf can be used as capital formation and purchase of fixed assets, while the salaries of the employees are paid from the proceeds of the leased asset. Apart from that, IWB can be established in the same way as other corporate banks. This method is easier than the raised waqf fund that takes some time to reach the required amount. In terms of legislation, IWB can collaborate with each SIRC. But the problem is if the establishment of the bank was delayed, then collected cash waqf is stagnant from its original purpose as the true intention of a waqif is dedicating his property to the establishment of IWB. So, the management should ensure that the establishment of this bank is done in order to avoid any inconvenience (Respondent AA0005).

The easiest way to develop IWB is using the same procedures like other corporate banks. IWB can adapt the same Islamic banking activities same as other Islamic banks. To carry out waqf activities, IWB can adapt the way conventional banks that have Islamic window, which Islamic banks that have waqf window. IWB can use this example to be applied into their operation which is Islamic banking system that has waqf window. The more effective way is, corporate bank shareholders that have access to waqf window surrender their shares as waqf. The bank is entirely waqf oriented (Respondent AA0005).

However, this bank should operate as a corporate bank in advance and brings benefit to the shareholders of this bank which later surrender their shares as waqf. Perhaps in this way, it can attract investors to set up a bank that will benefit them in this world and the hereafter. The bank also may establish a subsidiary company arising from the rental of buildings to increase revenue from the rental of buildings or fixed assets. IWB can take the Hong Leong Group as an example. Hong Leong Group has many subsidiaries to 
strengthen its financial position and generate more income while ensuring that the group will not experience bankruptcy. In terms of capital requirements, the possible minimum capital basis is RM300 million. There are also requirements in terms of how the capital should be calculated based on asset risk, business risk, and so many acts that IWB needs to arbitrate (Respondent AA0005).

Meanwhile, the bank's direction must coincide with the original purpose of the establishment of the bank as well as waqf funds in order to expand the growth of the fund. In addition, IWB has to try to get the GLC companies to dedicate their cash waqf for the establishment of this bank. This is because the GLC companies have a lot of cash. If they do not have cash liquidity, they can get cash from the financial market to raise cash to contribute to the establishment of the waqf bank. Nonetheless, all these attempts need fully support and collaboration from many parties who have different objectives and not only for the hereafter purpose (Respondent CA0002).

\subsection{Risky Investment}

Zakat has a time frame of one year to distribute to the zakat beneficiary, unlike waqf, it has no time frame. That is the advantage of waqf, it can be invested to gain more profit. To maximize the revenue from waqf activity, IWB could invest the rental income from waqf property. IWB can start with low risk investments or investments that are supported by the government. For example, IWB could invest in GLC companies or money market. Money market here means Islamic bonds that are being issued by Malaysian government (Respondent BB0004).

Following the example of Tabung Haji (TH), IWB could invest in buying hotels in Mecca. Considering the ruling of waqf is permanent, IWB do not have any problem in buying hotel buildings. In terms of profit, 2 hotels in Mecca is much more profitable compared to 10 hotels in Malaysia. IWB can obtain more profit by investing in Mecca hotel buildings rather than Malaysia's hotel buildings (Respondent AA0002). 
Investment in unit trust and share market is good for increasing the Malaysian GDP. To invest in unit trust and share market, again IWB needs to use the rental income from waqf properties. This is because the investment in unit trust and stock is very risky. The price of stock and unit trust is unstable and change daily. It could change in an upward or downward trend. That is why IWB needs to use the rental income gained from waqf properties (Respondent BB0004).

Moreover, IWB could also invest in SME. For example IWB could invest in halal food production industry such as production of halal burger, production of halal soft drinks, production of halal snacks, etc. Other than food production, IWB could also invest in any franchise businesses such as Petronas pump station, Secret Recipe, Aunty Anne's, Kenny Rogers, etc. Half or $1 / 3$ of the profit is returned to IWB. If IWB is successfully being developed and have control over the banking institutions, such as monitoring the bank's activities, then IWB can proceed to invest in banking product such as mudarabah investment, musharakah investment, Islamic fixed deposit, house financing, car financing, personal financing, etc. (Respondent AB0003).

In addition, IWB could establish subsidiary companies as an investment. Again take $\mathrm{TH}$ as an example. TH has subsidiary companies such as TH Plantation, TH Transport, TH Property, etc. IWB can apply this concept in IWB investment management. Again the investment funds must come from rental income of waqf properties. An investment is very risky, any investment is a risk. Thus, the management of the waqf bank should be careful when making any decision to invest in any place whatsoever, and should ensure that it is invested in a shariah-compliant investment (Respondent BA0002).

Apart from that, IWB can also invest in import and export business. This is because trading is a very profitable business. Most muslims today do not invest a lot and do not provide enough funding for research in the field of investment. As a trustee of cash waqf, it is best to invest in non-depreciating activity. As for shares of stock, it is risky in terms of market prices. Stock price volatility and changing from day to day, and the changes do not always go up (Respondent AA0005). 


\subsection{Experts in the Field of Waqf and Islamic Banking}

IWB needs experts in waqf and Islamic banking field. Therefore, SIRC and Islamic bank should cooperate to establish IWB as this cooperation is essential in view of the fact that both organizations could monitor any waqf related activities at each state regularly.

The concept of Islamic banking business is the bank would purchase a non-movable asset like a premise which can later be sold and buyer pays by installment. From the perspective of Islamic banking system, if the system can be transformed into waqf banking system that buys and later rent out so that the revenues can be channelled to the tawzi' fund, then this bank could be established. IWB can fully operate as other Islamic banks (Respondent AA0005).

A bank has its own specific departments such as operation department to manage current account, saving, fixed deposit, cash management, and remittance. This is the basic concept of a bank's operation. Thus, the IWB needs to have a credit department to run activities such as providing financing. In addition, the consumer part is handled by Operation Department, Bancassurance Department, Credit Department, and Share Investment Department. This is the foundation of consumer banking. Current account, saving account, fixed deposit, cash management, and remittance are placed under Operation Department. While loans such as consumer loan, mortgage, ASB loan, and other loans are under Credit Department. Each department has its own officers to handle specific duties. Therefore, IWB needs to have many skilled staffs and experts in order to be operated effectively and these skilled individuals are very limited in this country (Respondent CA0001).

\subsection{Legal and Regulation Requirements}

Based on Malaysia legal aspect, the mu'amalah law has been applied by the federal government by creating Islamic banking act. Meanwhile, from the Islamic legislative aspect, it is subject under the jurisdiction of the state government, not the federal government. Therefore, the Islamic banking system is under the Islamic legal system and should be under the jurisdiction of the state government. Since the Islamic banking system is considered a financial matter, it 
is therefore under the jurisdiction of the federal government (Respondent AA0005).

If the cash waqf can be considered as a financial matter, the federal government can also create a waqf banking system. Another way to solve this problem is to create waqf banking act. This provides a better and effective way as there is no such barrier after waqf bank's act is accomplished. Nevertheless, to create a new waqf banking act is not easy especially to harmonize the application of the different waqf enactments from different states (Respondent AA0005).

\section{CONCLUSION}

From the above discussion, it shows that there is possible structure for waqf mechanism that can be implemented for the realization of IWB. Again the discussion about cash waqf needs to be more extensive to find the best system and model to develop the IWB for the benefit of the ummah. Since maslahah is very important for the ummah, the development of IWB will ensure the achievement of economic well-being for oneself, society, and nation at large. The permissibility of cash waqf for the realization of IWB is important in making sure the structure and operation of the bank will run smoothly. Indeed, the realization of IWB will benefit the donor, beneficiaries, and the general public of the society. It is suggested that in the future research, the willingness of muslim community in contributing fund for this Islamic waqf bank should be studied since a large amount of fund is needed in making sure that the development of this institution becomes a success. Besides, the study on the willingness of various parties in the waqf and Islamic banking industries to collaborate also should be done in order to realize the development of the IWB in the future.

\section{ACKNOWLEDGEMENT}

This research is benefited from the funding of the Exploratory Research Grant Scheme (ERGS) of the Ministry of Higher Education, Malaysia (The Establishment of Islamic Waqf Bank Model for Financing in Education) (JPT:ERGS/1/2012/SS07/USIM/02/2, USIM: USIM/ERGS-FEM-33-50212). 


\section{REFERENCES}

Ahrens, T., \& Chapman, C. S. (2006). Doing qualitative field research in management accounting: Positioning data to contribute to theory. Accounting, Organizations and Society, 31(8), 819841.

Chowdhury, M. S. R., Ghazali, M. F., \& Ibrahim, M. F., (2011). Economics of cash waqf management in Malaysia: A proposed cash waqf model for practitioners and future researchers. African Journal of Business Management, 5(30), 12155-12163.

Çizakça, M. (1998). Awqaf in history and its implications for modern Islamic economies. Islamic Economic Studies, 6(1), 43-70.

Çizakça, M. (2004). Incorporated cash waqfs and mudaraba, Islamic non-bank financial instruments from the past to the future. Istanbul, Turkey: Bahcesehir University.

Çizakça, M. (2010). Incorporated cash waqfs and mudaraba, Islamic non-bank financial instruments from the past to the future (MPRA Paper). Retrieved from http://mpra.ub.uni-muenchen. de/25336

Mohammad, M. T. S. H., \& Iman, A. H. H. M. (2006). Obstacles of the current concept of waqf to the development of waqf properties and the recommended alternative. Malaysian Journal of Real Estate, 1(1).

Irvine, H. \& Gaffikin, M. (2006). Getting in, getting on and getting out: Reflections on a qualitative research project. Accounting, Auditing \& Accountability Journal, 19(1), 115-145.

Islahi, A. A. (1992). Provision of public goods: Role of the voluntary sector (waqf) in Islamic history. Proceedings of Seminar on Financing Development in Islamic Economics. Jeddah: IRTI-IDB.

Islamic Financial Services Industry Financial Stability Report. (2015). Kuala Lumpur: Bank Negara Malaysia.

Kahf, M. (1998, March). Financing the development of awqaf property. Paper prepared for the Seminar on Development of Awqaf, organized by IRTI, Kuala Lumpur, 2-4 March 1998. 
Laila, T. (n.d.). Innovations in Islamic philanthropy and monetization of Islamic philanthropic instruments. Bangladesh: Institute of Hazrat Mohammad SAW.

Marginson, D. E. W. (2004). The case study, the interview and the issue: A personal reflection. In C. Humphrey, \& B. Lee (Eds.), The real life guide to accounting research: $A$ behind-the-scenes view of using qualitative research methods (pp. 325-337). Amsterdam: Elsevier.

Mohammad, M. T. S. H. (2008). Sustaining the means of sustainability: The need for accepting wakaf (waqf) assets in Malaysian property market. Presented at The $14^{\text {th }}$ Annual Conference of the Pacific Rim Real Estate Society, Kuala Lumpur, Malaysia.

Mohammad, M. T. S. H. (2011). Towards an Islamic social (waqf) bank. International Journal of Trade, Economics and Finance, 2(5), 381-386.

Aziz, M. R. A. (2012). Introduction to Islamic institutions in economics and finance. Bandar Baru Nilai: USIM Press.

Aziz, M. R. A. et al. (Eds.) (2014). Waqf financing for higher education: Issues, challenges and the way forward. Bandar Baru Nilai: USIM Press.

O'Dwyer, B. (2004). Qualitative data analysis: Illuminating a process for transforming a 'messy' but 'attractive' 'nuisance'. In C. Humphrey, \& B. Lee (Eds.), The real life guide to accounting research: A behind-the-scenes view of using qualitative research methods (pp. 391-407). Amsterdam: Elsevier.

Promoting charity via waqf. (2014, April 15). The Star Online.

Shahih Muslim. (2000). Riyadh: Darussalam.

Toraman, C., Tuncsiper, B., \& Yilmaz, S. (n.d.). Cash awqaf in the Ottomans as philanthropic foundations, and their accounting practices. Retrieved from journal.mufad.org

Wafa, S. M. G. W. S. A. (2010, January). Development of waqfs for education in Malaysia. Working paper presented on the $7^{\text {th }}$ International Conference - The Tawhidi Epistemology: Zakat and Waqf Economy, Bangi. 